\title{
Faktor Determinan yang Berhubungan dengan Upaya Pengendalian Hipertensi di PSTW Budi Luhur Kota Jambi
}

\author{
Fithriyani ${ }^{1}$, Miko Eka Putri ${ }^{2}$ \\ ${ }^{1-2}$ Dosen Program Studi Ilmu Keperawatan,Stikes Baiturahim \\ E-mail: fithri.yani25@yahoo.co.id
}

Submitted :01 /04/2020

Accepted: $15 / 04 / 2020$

Published: 7/09/2020

\begin{abstract}
Aging is a natural process that can not be avoided, running continuously, and continuously. Based on population projection data the number of elderly people will increase where the most number is found at the age of 60-64 years 94,012 people. Increasing age decreases bodily functions, decreased organ function and changes in blood pressure, therefore the elderly are advised to check their blood pressure regularly. As they age, blood pressure in the elderly will increase so that there is a higher risk of developing hypertension. Hypertension is a major health problem throughout the world, causing a high prevalence and is associated with an increased risk of cardiovascular disease. Some things that need to be considered in an effort to control hypertension include regular exercise, adequate rest, medical, traditional, regulate diet and reduce salt consumption one teaspoon per day. The purpose of this study was to determine the determinants and factors associated with efforts to control hypertension in the elderly at PSTW Budi Luhur, Jambi City. The research method uses descriptive analysis design with cross sectional approach. Samples were conducted for the elderly with hypertension. The research instrument was in the form of questionnaire sheets by interview. The results obtained $40 \%$ of elderly people have a history of smoking, 45\% are quite good in consuming food, $60 \%$ elderly with moderate activity and $60 \%$ elderly are good in controlling hypertension. The results of bivariate analysis showed that there was no correlation between determinant factors (smoking history, food consumption, physical activity) and hypertension control efforts in the elderly in PSTW Budi Luhur, Jambi City.
\end{abstract}

Keywords: control of hypertension, consuming food, elderly, history of smoking

\begin{abstract}
Abstrak
Penuaan adalah suatu proses alami yang tidak dapat di hindari, berjalan secara terus-menerus, dan berkesinambungan. Berdasarkan data proyeksi penduduk jumlah lansia akan semakin meningkat dimana jumlah paling banyak terdapat pada umur 60-64 tahun 94.012 orang. Semakin bertambah umur semakin berkurang fungsi-fungsi organ tubuh, penurunan fungsi organ dan mengalami perubahan tekanan darah oleh sebab itu lansia di anjurkan untuk memeriksa tekanan darah secara teratur.Seiring dangan bertambahnya usia maka tekanan darah pada lansia akan bertambah tinggi sehingga lebih beresiko terkena hipertensi. Hipertensi merupakan masalah kesehatan besar di seluruh dunia penyebab tingginya prevalensi dan berhubungan dengan peningkatan resiko penyakit kardiovaskuler. Beberapa hal yang perlu diperhatikan dalam upaya pengendalian hipertensi antara lain olah raga teratur, istirahat yang cukup, medis, tradisional, mengatur pola makan dan mengurangi konsumsi garam satu sendok teh perhari. Tujuan penelitian ini untuk mengetahui determinan dan faktor yang berhubungan dengan upaya pendendalian hipertensi pada Lansia di PSTW Budi Luhur Kota Jambi. Metode penelitian menggunakan desain analisis deskriptif dengan pendekatan cross sectional. Sampel dilakukan terhadap lansia dengan hipertensi. Instrument penelitian berupa lembar kuesioner dengan cara wawancara. Hasil penelitian didapat $40 \%$ lansia memiliki riwayat merokok, $45 \%$ cukup baik dalam mengkonsumsi makanan, $60 \%$ lansia dengan aktivitas sedang dan 60\% lansia baik dalam upaya pengendalian hipertensi. Hasil analisa bivariat didapatkan tidak ada hubungan factor determinan (riwayat merokok, konsumsi makanan,aktivitas fisik) dengan upaya pengendalian hipertensi pada lansia di PSTW Budi Luhur Kota Jambi.
\end{abstract}

Kata kunci: konsumsi makanan, lanjut usia, pengendalian hipertensi, riwayat merokok 


\section{PENDAHULUAN}

Penuaan adalah suatu proses alami yang tidak dapat di hindari, berjalan secara terus-menerus, dan berkesinambungan. Selanjutnya akan menyebabkan perubahan anatomis, fisiologis, dan biokimia pada tubuh sehingga mempengaruhi fungsi dan kemampuan tubuh secara keseluruhan. Menurut Kemenkes RI (2017) Berdasarkan data proyeksi penduduk, diperkirakan tahun 2017 terdapat 23,66 juta jiwa penduduk lansia di Indonesia (9,03\%). Diprediksikan jumlah penduduk lansia tahun $2020(27,08$ juta), tahun 2025 (33,69 juta), tahun 2030 (40,95 juta) dan tahun 2035 (48,19 juta). Lansia akan mengalami proses penuaan, diman menghilangnya secara perlahanlahan kemampuan jaringan untuk memperbaiki diri atau mengganti dan mempertahankan fungsi normalnya sehingga tidak dapat bertahan terhadap infeksi dan memperbaiki kerusakan yang diderita. (Constantanides, 1994 dalam Siyoto dkk, 2016).

Data Badan Pusat Statistik (BPS) Provinsi Jambi (2018) terdapat 232.994 orang lansia dimana jumlah paling banyak terdapat pada umur 60-64 tahun 94.012 orang. Jumlah lansia di Panti Sosial Tresna Werdha Budi Luhur Jambi terdapat 69 orang lansia dimana jumlah paling banyak berumur 65-69 berjumlah 28 orang lansia. Dengan Penyakit rematik dengan jumlah 36 lansia dan di ikuti oleh hipertensi dengan jumlah 20 lansia.

Hipertensi merupakan masalah kesehatan besar di seluruh dunia penyebab tingginya prevalensi dan berhubungan dengan peningkatan resiko penyakit kardiovaskuler. Berdasarkan WHO tahun 2010 sekitar 972 juta atau 26,4\% jiwa di seluruh dunia menderita hipertensi dengan perbandingan $26,6 \%$ pria dan $26,1 \%$ wanita. Dari 972 juta orang yang menderita hipertensi 333 juta terdapat di negara maju dan 639 juta sisanya berada di daerah negara berkembang termasuk indonesia, jumlah kasus hipertensi di seluruh dunia diperkirakan meningkat menjadi 1,5 miliar jiwa pada tahun yang akan datang (Muhammadun, 2010).

Faktor yang berperan terjadinya hipertensi pada usia lanjut adalah peningkatan sensitivitas terhadap asupan natrium, penurunan elastisitas pembuluh darah perifer yang diakibatkan oleh proses menua sehingga akan mengakibatkan tekanan darah akan meningkat (Martono, 2006). Penyebab hipertensi dibagi tiga yaitu secara genetic dimana faktor genetik menyebabkan kelaian berupa gangguan fungsi barostat renal, sensitifitas terhadap konsumsi garam, abnormalitas transfortasi natrium kaliaum, gangguan metabolisme. Faktor lingkungan dibagi menjadi tiga bagian yaitu terakhir adaptasi struktural jantung serta pembuluh darah (Pudiastuti, 2011). Faktor-faktor yang mempengaruhi hipertensi adalah genetik, obesitas, stres karena lingkungan dan hilangnya elastisitas jaringan (Aspiani, 2016).

Menurut Gunawan (2001), untuk menghindari terjadinya komplikasi hipertensi yang fatal, maka penderita perlu mengambil tindakan pencegahan yang baik (stop high blood pressure). Upaya pencegahan komplikasi hipertensi ini dapat dilakukan dengan pengendalian hipertensi. Beberapa upaya yang dilakukan untuk mengendalikan hipertensi antara lain dengan olah raga teratur, istirahat yang cukup, medis, tradisional,mengatur pola makan dan mengurangi konsumsi garam satu sendok teh perhari (Muhammadun, 2010).

Tujuan penelitian ini adalah untuk mengetahui faktor determinan yang berhubungan dengan upaya pengendalian hipertensi pada lansia di PSTW Budi Luhur Kota Jambi Tahun 2019. Rumusan masalah yang diambil adalah factor determinan apakah yang berhubungan dengan upaya pengendalian hipertensi pada lansia di PSTW Budi Luhur Kota Jambi Tahun 2019. 


\section{METODE PENELITIAN}

Penelitian ini dilakukan pada lansia penderita hipertensi di Panti Sosial Tresna Werdha Budi Luhur Kota Jambi pada bulan Mei 2019 sebanyak 20 orang. Instrumen penelitian yang digunakan dalam penelitian ini adalah dengan menggunakan kuesioner .Pada penelitian ini, kuesioner tidak dilakukan uji validitas dan reabilitas disebabkan karena kuesioner stres diadopasi dari buku Lestari (2015), dan kuesioner aktivitas fisik diadopsi dari IPAQ (International Physical Activity Questionare). Variabel yang diteliti antara lain umur, jenis kelamin, aktivitas fisik, kebiasaan merokok, konsumsi makanan dan upaya pengendalian hipertensi. Data dianalisis secara univariat dan bivariat dengan menggunakan uji chi square.

\section{HASIL DAN PEMBAHASAN}

\section{A. Karakteristik Responden \\ 1. Umur}

Hasil penelitian didapatkan bahwa distribusi frekuensi responden berdasarkan umur bahwa distribusi responden berdasarkan umur $70 \%$ (14) responden dikategorikan elderly (60-74 tahun). Pasien dengan usia diatas 60 tahun memiliki resiko menderita hipertensi. Hal ini disampiakan dalam Triyanti (2014) bahwa Factor usia sangat berpengaruh terhadap kejadian hipertensi karena dengan bertambahnya usia maka semakin tinggi mendapat resiko hipertensi.

\section{Jenis kelamin}

Distribusi responden berdasarkan jenis kelamin $70 \%$ (14) responden berjenis kelamin laki-laki. Menurut Triyanto (2014) jenis kelamin sangat erat kaitannya terhadap terjadinya hipertensi pada masamuda dan usia paruh baya lebih tinggi menderita hipertensi pada laki-laki.

\section{B. Analisa Univariat}

\section{Riwayat Merokok}

Tabel 1. Distribusi frekuensi responden berdasarkan riwayat merokok di Panti
Sosial Tresna Werdha Budi Luhur Kota Jambi Tahun 2019

\begin{tabular}{lll}
\hline Riwayat merokok & frekuensi & $\%$ \\
\hline Tidak merokok & 12 & 60 \\
Merokok & 8 & 40 \\
Jumlah & 20 & 100 \\
\hline
\end{tabular}

Berdasarkan tabel diatas didapatkan bahwa distribusi responden berdasarkan riwayat merokok $40 \%$ (8) responden memiliki riwayat merokok. Kandungan rokok dapat menempel pada dinding pembuluh darah manusia, jika dilakukan dalam waktu yang lama penumpukan zat nikotin dan tar dapat menimbulkan plak yang dapat mengakibatkan terjadinya penyumbatan pembuluh darah dan keelastisan pembuluh darah menurun. Penyumbatan ini yang dapat memicu peningkatan tekanan darah. Hasil penelitian Setyanda, 2015 menunjukkan bahwa ada hubungan kebiasaan meroko dengan hipertensi ( $\mathrm{p}$ value $=0,003$ ). Hal ini dipengaruhi oleh lama merokok dan jenis rokok.

\section{Konsumsi makanan}

Tabel 2. Distribusi frekuensi responden berdasarkan Konsumsi Makanan di Panti Sosial Tresna Werdha Budi Luhur Kota Jambi Tahun 2019

\begin{tabular}{lcc}
$\begin{array}{l}\text { Konsumsi } \\
\text { makanan }\end{array}$ & Frekuensi & $\%$ \\
\hline Kurang baik & 4 & 20 \\
Cukup baik & 9 & 45 \\
Baik & 7 & 35 \\
Jumlah & 20 & 100 \\
\hline
\end{tabular}

Berdasarkan tabel diatas didapatkan bahwa konsumsi makanan pada lansia dengan hipertensi di PSTW Budi Luhur $45 \%$ cukup baik. $20 \%$ nya kurang baik dikarenakan masih mengkonsumsi minuman yang mengandung kafein seperti kopi dan teh. Pengaruh pola makan terhadap hipertensi masih kontroversi dan belum diketahui dengan pasti. Penelitian ini hanya mendapatkan konsumsi minuman bekafein yang ditemukan berisiko hipertensi. 
3. Aktivitas fisik

Tabel 3. Distribusi frekuensi responden berdasarkan aktivitas Fisik di Panti Sosial Tresna Werdha Budi Luhur Kota Jambi Tahun 2019

\begin{tabular}{lcc}
\hline Aktivitas fisik & frekuensi & $\%$ \\
\hline Ringan & 8 & 40 \\
Sedang & 12 & 60 \\
Jumlah & 20 & 100 \\
\hline
\end{tabular}

Berdasarkan table diatas didapatkan bahwa aktivitas fisik lansia dengan hipertensi memiliki aktivitas sedang $60 \%$. Melakukan aktivitas secara teratur (aktivitas fisik aerobik selama 30-45 menit/hari) diketahui sangat efektif dalam mengurangi risiko relatif hipertensi hingga mencapai $19 \%$ hingga $30 \%$. Begitu juga halnya dengan kebugaran kardio respirasi rendah pada usia paruh baya diduga meningkatkan risiko hipertensi sebesar 50\%. Penelitian ini mendapatkan hasil yang sejalan, yaitu adanya risiko hipertensi pada mereka yang kurang aktifitas fisik.

\section{Upaya Pengendalian}

Tabel 4. Distribusi Frekuensi Responden Berdasarkan Upaya Pengendalian Hipertensi Di Panti Sosial Tresna Werdha Budi Luhur Kota Jambi Tahun 2019

\begin{tabular}{lcc}
\hline $\begin{array}{l}\text { Upaya } \\
\text { pengendalian }\end{array}$ & frekuensi & $\%$ \\
\hline Kurang baik & 8 & 40 \\
Baik & 12 & 60 \\
Jumlah & 20 & 100 \\
\hline \multicolumn{2}{c}{ Berdasarkan tabel diatas didapatkan }
\end{tabular}

bahwa distribusi responden berdasarkan upaya pengendalian hipertensi $60 \%$

responden baik. Hasil penelitian Dalyoko (2010) menunjukkan bahwa sebagian besar $(65,7 \%)$ lansia memiliki sikap kurang baik dalam pengendalian hipertensi.

\section{Analisa Bivariat}

1. Hubungan riwayat merokok dengan upaya pengendalian hipertensi

Tabel 5. Hubungan riwayat merokok dengan upaya pengendalian hipertensi pada lansia di PSTW Budi Luhur Kota Jambi tahun 2019.

\begin{tabular}{lccccccc}
\multicolumn{9}{c}{ Upaya } & & P-value \\
& pengendalian & & & & \\
\hline $\begin{array}{l}\text { Riwayat } \\
\text { merokok }\end{array}$ & $\mathrm{f}$ & $\%$ & $\mathrm{f}$ & $\%$ & $\mathrm{f}$ & $\%$ & 0.167 \\
$\begin{array}{l}\text { Tidak } \\
\text { merokok }\end{array}$ & 3 & 25 & 9 & 75 & 12 & 100 & \\
$\begin{array}{l}\text { Merokok } \\
\text { total }\end{array}$ & 5 & 62,5 & 3 & 37,5 & 8 & 100 & \\
\hline \multicolumn{7}{c}{ Berdasarkan } & \multicolumn{3}{c}{ hasil } & & penelitian
\end{tabular}

hubungan antara riwayat merokok dengan upaya pengendalian hipertensi didapatkan $\mathrm{p}$ value $0,167(<0,05)$ yang artinya tidak ada hubungan antara riwayat merokok dengan upaya pengendalian hipertensi. Sejalan dengan penelitian Retnowati (2010) didapatkan hasil tidak ada hubungan yang signifikan antara kebiasaan merokok dengan kejadian hipertensi. Hubungan merokok dengan hipertensi memang belum jelas. Menurut literatur, nikotin dan karbondioksida yang terkandung dalam rokok akan merusak lapisan endotel pembuluh darah arteri, elastisitas pembuluh darah berkurang sehingga menyebabkan tekanan darah meningkat (Depkes,2007).

2. Hubungan konsumsi makanan dengan upaya pengendalian hipertensi Tabel 6. Hubungan konsumsi makanan dengan upaya pengendalian hipertensi pada lansia di PSTW Budi Luhur Kota Jambi tahun 2019

Upaya pengendalian

\begin{tabular}{|c|c|c|c|c|c|c|c|}
\hline \multirow[t]{2}{*}{$\begin{array}{l}\text { Konsumsi } \\
\text { makanan }\end{array}$} & \multicolumn{2}{|c|}{$\begin{array}{c}\text { Kurang } \\
\text { baik }\end{array}$} & \multicolumn{2}{|c|}{ Baik } & \multicolumn{2}{|c|}{ Total } & value \\
\hline & $\mathrm{f}$ & $\%$ & $\mathrm{f}$ & $\%$ & $\mathrm{f}$ & $\%$ & \\
\hline $\begin{array}{l}\text { Kurang } \\
\text { baik }\end{array}$ & 3 & 75 & 1 & 25 & 4 & 100 & \\
\hline $\begin{array}{l}\text { Cukup } \\
\text { baik }\end{array}$ & 3 & 3.3 & 6 & 6,7 & 9 & 100 & 0,274 \\
\hline Baik & 2 & 8,6 & 5 & 1,4 & 7 & 100 & \\
\hline Total & 8 & 40 & 12 & 60 & 20 & 100 & \\
\hline
\end{tabular}


$\mathrm{p}$ value $0,274>0,05$, artinya tidak ada hubungan antara konsumsi makanan dengan upaya pengendalian hipertensi pada lansia di PSTW Budi Luhur Kota Jambi. Pengaruh pola makan terhadap hipertensi masih kontroversi dan belum diketahui dengan pasti (Kaplan, 2002). Penelitian ini hanya mendapatkan konsumsi minuman bekafein yang ditemukan berisiko hipertensi. Hal ini mungkin disebabkan kualitas data pola konsumsi pada Riskesdas 2007 yang cenderung subjektif karena belum diukur secara kuantitatif (hanya diukur melalui frekuensi konsumsi). Di lain pihak pengaruh pola makan kemungkinan berkaitan dengan kegemukan. Menurut Sunyer, kelompok obes dan hiperkolesterol mempunyai risiko hipertensi yang lebih tinggi (2,9 kali dan 3,2 kali) dibandingkan yang normal.

3. Hubungan aktivitas fisik dengan upaya pengendalian hipertensi

Tabel 7. Hubungan aktivitas fisik dengan upaya pengendalian hipertensi pada lansia di PSTW Budi Luhur Kota Jambi tahun 2019

\begin{tabular}{|c|c|c|c|c|c|c|c|}
\hline & \multicolumn{6}{|c|}{ Upaya pengendalian } & $P-$ \\
\hline \multirow[t]{2}{*}{$\begin{array}{l}\text { Aktivitas } \\
\text { fisik }\end{array}$} & \multicolumn{2}{|c|}{$\begin{array}{c}\text { Kurang } \\
\text { baik }\end{array}$} & \multicolumn{2}{|c|}{ Baik } & \multicolumn{2}{|c|}{ Total } & \\
\hline & $\mathrm{f}$ & $\%$ & $\mathrm{f}$ & $\%$ & $\mathrm{f}$ & $\%$ & \\
\hline Ringan & 5 & 62,5 & 3 & 37,5 & 8 & 100 & \\
\hline Sedang & 3 & 25 & 9 & 75 & 12 & 100 & 0,0 \\
\hline Total & 8 & 40 & 12 & 60 & 20 & 100 & 94 \\
\hline
\end{tabular}

Berdasarkan table diatas didapatkan bahwa $p$ value $0,094(>0,05)$ yang artinya tidak ada hubungan antara aktivitas fisik dengan upaya pengendalian hipertensi. Namun p-value yang hampir mendekati 0,05, maka bisa dimaknakan hampir berhubungan aktivitas fisik dengan upaya pengendalian hipertensi pada lansia. Aktivitas fisik merupakan istilah umum untuk segala sesuatu pergerakan tubuh karena aktivitas otot yang akan menghasilkan meningkat kan kebutuhan energi (Soegih \& Wiramihardja, 2009). Melakukan aktivitas secara teratur (aktivitas fisik aerobik selama 30-45 menit/hari) diketahui sangat efektif dalam mengurangi risiko relatif hipertensi hingga mencapai $19 \%$ hingga $30 \%$. Begitu juga halnya dengan kebugaran kardio respirasi rendah pada usia paruh baya diduga meningkatkan risiko hipertensi sebesar 50\%. Berdasarkan table diatas didapatkan bahwa p value 0,094 $(>0,05)$ yang artinya tidak ada hubungan antara aktivitas fisik dengan upaya pengendalian hipertensi. Namun p-value yang hampir mendekati 0,05 , maka bisa dimaknakan hampir berhubungan aktivitas fisik dengan upaya pengendalian hipertensi pada lansia.

\section{SIMPULAN}

Distribusi responden berdasarkan riwayat merokok pada lansia dengan hipertensi di PSTW Budi Luhur hampir separoh $(40 \%)$ responden memiliki riwayat merokok, berdasarkan konsumsi makanan pada lansia dengan hipertensi di PSTW Budi Luhur hampir separoh $(45 \%)$ cukup baik, distribusi responden berdasarkan aktivitas fisik memiliki sebagian besar $(60 \%)$ aktivitas sedang dan distribusi responden berdasarkan upaya pengendalian hipertensi sebagian besar $60 \%$ responden baik.

Tidak ada hubungan antara riwayat merokok dengan upaya pengendalian hipertensi pada lansia di PSTW Budi Luhur ( $p$-value 0,167). Tidak ada hubungan antara konsumsi makanan dengan upaya pengendalian hipertensi pada lansia di PSTW Budi Luhur (p-value 0,274). Tidak ada hubungan antara aktivitas fisik dengan upaya pengendalian hipertensi pada lansia di PSTW Budi Luhur ( $p$-value 0,094).

Disarankan kepada patugas panti dan pimpinan dapat memberikan programprogram tentang upaya pengendalian hipertensi pada lansia di Panti Sosial Tresna Werdha Budi Luhur Kota Jambi dalam meningkatkan status kesehatan bagi lansia. 
DAFTAR PUSTAKA

Anggara. 2013. Faktor-Faktor Yang Berhubungan Dengan Tekanan Darah Di Puskesmas Telaga Murni, Cikarang Barat Tahun 2012. Jurnal Ilmiah Kesehatan, 5(1); Jan 2013

Aspiani. 2014. Buku Ajar Asuhan Keperawatan Klien Gangguan Kardiovaskuler. Jakarta : EGC.

Darmojo. 2015. Buku Ajar Geriatri. Semarang: Fakultas Kedokteran Universitas Indonesia.

Harison. 2013. Buku Saku Kardiovaskuler. Tangerang Selatan : Karisma.

Lalage, Z. (2015). Hidup Sehat Dengan Terapi Air Cetakan Pertama. Klaten : Abata Press.

Muhammadun AS. 2010. Hidup Bersama Hipertensi. Jogjakarta : In-Books

Rahajeng, E . 2009. Prevalensi Hipertensi dan Determinannya di Indonesia. Majalah Kedokteran Indonesia, Volume: 59, Nomor: 12, Desember 2009.

Udjianti, Wajan Juni. (2010). Keperawatan Kardiovaskuler. Jakarta : Salemba Medika.

Setyanda, Y. O. G., Sulastri, D., \& Lestari, Y. (2015). Hubungan merokok dengan kejadian hipertensi pada lakilaki usia 35-65 tahun di Kota Padang. Jurnal kesehatan andalas, 4(2).

Soesanto, e. (2012). Analisis faktor faktor yang berhubungan dengan praktik lansia hipertensi dalam mengendallkan kesehatannya di puskesmas mranggen demak. Fikkes, 3(2).

Syiddatul, B. (2019). Pengaruh Pemberian Kompres Hangat Jahe Terhadap Skala Nyeri Kepala Hipertensi Pada Lansia Di Posyandu Lansia Karang Werdha Rambutan Desa Burneh Bangkalan. Jurnal Kesehatan,5(1),

\section{1-7.}

Ferawati, F., \& Kep, m. (2017). Efektifitas kompres jahe merah hangat dan kompres serai terhadap penurunan intensitas nyeri arthritis remathoid pada lanjut usia di desa mojoranu kecamatan dander kabupaten bojonegoro. Jurnal ilmu kesehatan makia, 5(1), 1-9.

Putri, m. E. (2018). Korelasi jumlah batang rokok dengan kadar co pada remaja perokok di smk kota jambi. Jurnal akademika baiturrahim jambi,7(2), 123-129.

Muhith , abdul dan Sandu Siyanto ( 2016). Pendidikan Keperawatan Gerontik. Yogyakarta : Andi Offset.

Putri, M. E. (2019). Korelasi Stres dan Aktivitas Fisik dengan Tekanan Darah pada Penderita Hipertensi Essensial. Jurnal Ilmiah Universitas Batanghari Jambi, 19(1), 147-151.

Sanghal, Akhil et all. 2012 An experimental study to evaluate the preventive effect of Zingiber officinale (ginger) on hypertension and hyperlipidaemia and its comparison with Allium sativum (garlic) in rats . journal of Medicinal Plants Research Vol. 6( 25) . 5 Juli 2012

Shaban, Ibrahim, Mohamed, et All 2017. Ginger: its's effect on blood pressure among hypertensive Patients. IOSR Journal of Nursing And Health Science. $\mathrm{E}$ issn $=2320-1950 \mathrm{p}$ issn $=$ 2320- 1940 vol 6 issue 5.

Retnowati, Y. 2010. Gambaran Hipertensi Dan Hubungannya Dengan Pola Makan, Gaya Hidup, Dan Status Gizi Pada Pralansia Dan Lansia Di Posbindu Kelurahan Bantar Jati Bogor Tahun 2010.Skripsi peminatan gizi kesmas.Fakultas universitas Indonesia 